body, as to other scientific agencies, an exceptional opportunity and responsibility for aiding in steadying the thought of the people by interpreting in some measure the meaning of the rapid advances now being made in scientific understanding of man and his environment. With the continuing growth of knowledge we see the universe increase in complexity and extend itself vastly in space and time. It is to be expected that adjustments in our scientific data will bring into continuous review much that pertains also to the fundamental philosophic and religious thought forming so important a part of the world's thinking. We should never blind ourselves to the fact that the people have philosophies now, and always will have them, and that consciously or subconsciously they have religious beliefs, also. Abundant national disasters, some of which we have seen in recent decades, have demonstrated fully that there is nothing more deadly than bad national philosophy, especially if it translate itself into terms of economic or political policy. Such beliefs never arise from attainment of the truth, but always from the lack of it.

The Academy will always be conservative in holding fast such knowledge as may seem securely founded, but it will never look with favour on the defence of any view merely because it has been held. The attitude of the Academy as representing truth-seeking and truth-accepting should have a continuous influence in stabilising thought. Though we may never be advocates of philosophic or religious systems, we should assist in that interpretation of the shifting panorama which the world seems to present when viewed through the eyes of science; and we should help to keep false assumptions from serving in the place of truth.

\section{Dr. Vernon Kellogg, Permanent Secretary of the National Research Council.}

The National Research Council was born of the National Academy of Sciences in strenuous days of war, even as the Academy itself was born during the throes of an earlier great conflict. Both came into existence for a first purpose of bringing science intensively to the aid of the nation in a time of terrible emergency. Science, which has been said to know no political boundaries, yet has its nationalistic phase. Scientific men also may be patriots.

Because of the rôle played by science during the War, and the even more important rôle it will inevitably play in the next great war-if such war must come-various philosophers and humanitarians have lifted their voices to decry science as an agent of evil and a promoter of human capacity to do grievous things. They charge against it not only its rôle in war, but also its rôle in the industrial revolution which has made too many men slaves of machines.

It is true that science has been used to do sad work. It is true that science can be used to make of the next war an earthly horror almost beyond conception. But is science to be held responsible if we choose to have war rather than peace? Let us put the responsibility where it justly falls: on governments and on ourselves. Because science can convert, in a day or two, a factory for the production of beautiful dyes, pleasant perfumes, and diseasedestroying drugs into a factory for the production of high explosives and poisonous gases, is science to be judged an enemy of humanity? Scientific men will never make this conversion unless you ask them to. They hope from their hearts that they will never again have to do this.

It is the other side of the picture that science prefers to have shown. It asks to have recognised the many contributions it has made to the well-being and happiness of mankind. It directs attention to its steady endeavour to satisfy the insistent demand of man to know the world he lives in, that he may live in it more comfortably and confidently and with more interest; to know the wide reaches of the universe that his mind and soul may understand humility and yet know exaltation. Science moves with constant acceleration in its work of increasing human knowledge, adding to human capacity and expanding human existence. By the very cumulation of knowledge more knowledge is made more rapidly possible. In the early days of prehistoric man before picturemaking and writing, man could not cumulate knowledge, or, at best, but slightly and slowly. But with the perfecting of means of communicating knowledge from one group to another and from one generation to another, the advance and cumulation of knowledge can proceed rapidly and ever more rapidly. In the present quarter century more knowledge of the order of Nature has been gained than in any quarter century before. One cannot dream too wildly of the possibilities of the future.

Let science, then, with all encouragement, play undisturbed its glorious peace-time rôle of bettering the lot of individuals, adding to the resources of nations, and widening man's understanding of Nature and of himself. Let it go on in its great beneficences : conquering disease ; ameliorating the wearing struggle for food and the cruel rigours of heat and cold; annihilating distance; reaping benefits from the oceans and forests, and bringing plants and animals to the service of man's sustenance and comfort. Let it continue to convert astrology into astronomy, alchemy into chemistry, guess-work into exact knowing. Let it use imagination to the limit-imagination is no less necessary to science than to the seven arts--but let its dreams be tested in the light of day. Let it prove all things, discover truth, and teach truth and the way of its discovery. Let it attend, undistractedly and unwearyingly, to its great effort to make our land a better land for our children and our children's children to live in, and the human future broader and better than the human present.

\title{
Annual Inspection of the Rothamsted Experimental Station.
}

THE annual meeting of the Society for Extending the Rothamsted Experiments was held at the Rothamsted Experimental Station, Harpenden, on Wednesday June $x 8$, when about 70 members of the Society and guests attended at the invitation of Lord Bledisloe, chairman of the Lawes Agricultural Trust. Among those present were Mr. Noel Buxton (Minister of Agriculture), Lord Salisbury, Earl de la Warr, Sir Thomas Middleton, Mrs. and Miss Muller, Dr. K. Fisher (Headmaster of Oundle), and the members of the Lawes Trust Committee. Both Mr. Lloyd George and Mr. Stanley Baldwin were compelled to cancel their acceptance owing to other public business.

As in previous years, arrangements were made for the visitors to see something of the work of the Station, both on the experimental fields and plots and in the laboratories. There are more than 500 experimental field plots on the farm and I 2 separate departments in the laboratories, so it is impossible in the course of a single day's visit to see more than a small section of the work.

The Rothamsted field plots fall into two groups: NO. 2852 , VOL. I I 3$]$ 
the classical experimental fields, the treatment of which is continued unchanged, from year to year, and the later experiments, laid out to test some definite point under present-day conditions. The latter group are, in one sense, sets of temporary experiments, and as a rule are replaced by others after a few seasons. The long spell of wet weather over the early part of this year has not only encouraged weeds but has retarded the growth of cereal crops, and there has been a general levelling up of the differences between the plants on various plots that would be apparent at this time of the year in a normal season. On the other hand, the growth on meadowland and hay fields has been very satisfactory.

The morning inspection of the plots was arranged to show both these effects, the fields selected for this purpose being the Park Grass plots, which have been cut for hay each year since 1856, and Hoos Field, which has been under barley since ${ }^{8} 5_{2}$. The Park Grass plots are always of great interest to visitors owing to the remarkable changes, brought about by the various combinations of manures, in the quantity and botanical composition of the herbage that was originally uniform in composition throughout the field. The plots on Hoos Field, that are now carrying the seventy-third successive barley crop, were next visited. For many years past these plots have demonstrated the importance of phosphate in encouraging early growth and hastening maturity of the plant, and the influence of this factor and others on malting-barley, which is normally grown in rotation and not continuously on the same land, has for some years been under investigation both at Rothamsted and at a number of outside centres in connexion with the Institute of Brewing Research Scheme. In addition to the malting barley series, other groups of plots on the farm have been laid out to test certain points that have arisen directly or indirectly from the Hoos Field results. Among these may be mentioned the extensive series dealing with the effect of silicates. Lawes and Gilbert used silicates on certain of the Hoos Field plots--and on Park Grass plots also-in connexion with Liebig's famous theory of plant nutrition; the treatment was carried on without change although the necessity had apparently ceased, and it will now be possible to make important comparisons between these plots and the series recently set up.

After luncheon Lord Bledisloe, who presided, addressed the company. He read a letter from the Prime Minister, who said that the production of food had not moved on with the same rapidity as the production of the other great necessities of life like textiles and metals. The best hope of advancement in this direction was in the application of research to the industry of agriculture. After some appreciative references to the Rothamsted Station, the letter concluded by stating that the Government, as evidence of its belief in the research, had assured to agricultural research such sums as could be usefully expended.

Lord Bledisloe then dealt with the practical significance of the work, and in particular the extensive co-operation between Rothamsted and outside bodies which are sharing in the experiments, and in many cases contributing liberally towards the cost of the research. In conclusion he expressed his conviction that it is in times of depression in the industry such as we are now passing through, that the research stations and agricultural schools are of greatest assistance.

The Minister of Agriculture congratulated the Station on its past and present record, and said that he had been impressed in his travels abroad by the number of people who were familiar with the work of the Station.

The Director, Sir John Russell, briefly reviewed the past year's work, referring especially to the large increase in the number of farmer visitors, of whom there had been more than 1300 in the year, a number that will be considerably exceeded in the present season. In addition, some 70 lectures were given by various members of the staff during the winter, at farmers' and students' meetings. In dealing with the laboratory work, he invited attention to the relation of the research work to practical conditions as shown by the financial aid given by outside bodies to various departments. Typical cases of this co-operative work were as follows: Entomology Department and the Imperial Bureau of Entomology on the control of pests by means of parasites, Chemistry and Bacteriology Departments with the Royal Agricultural Society on green manuring and lucerne inoculation respectively, Physics Department with the Empire Cotton Growing Corporation in connexion with soil moisture and acidity investigations, and the Chemistry Department with the Institute of Brewing on malting barley investigations, and with fertiliser manufacturers in fertiliser investigations.

Lord Salisbury briefly traced the early relations of the Station with Hertfordshire farming.

Sir Daniel Hall, chief scientific adviser to the Ministry of Agriculture, and a former Director of Rothamsted, reviewed the progress that had been made since the Government first gave financial assistance for agricultural research, and Dr. J. G. Lipman, Director of the New Jersey Agricultural Station, New Jersey, U.S.A., gave some interesting comparisons between the British and American organisations for research and education. Mr. Martin Sutton and Mr. Stratton also spoke. Mr. Stratton paid his first visit to Rothamsted sixty-three years ago. The guests then inspected the laboratories and discussed with the staff some of the investigations in progress.

\section{Association of Teachers in Technical Institutions.}

THE annual conference of the Association of Teachers in Technical Institutions was held at Newcastle-on-Tyne on June 9 and ro. In his presidential address, Mr. F. C. Clarke, of the Technical College, West Ham, emphasised the fact that technical education is not at present understood by many of our educationists. Mr. Fisher, in an article in the Teachers' World, wrote that he was able to compare in their effects upon national power the expenditure in technical education and pure science, and to declare without hesitation in favour of pure science. What did Mr. Fisher mean by technical education and pure science? How can one be separated from the other? They merge into each other at innumerable points.

In Mr. Clarke's opinion, one pressing question is the need for a committee of inquiry to investigate the relationship of technical to other branches of education and to industry and commerce. Considerations of the future demand a vigorous healthy Britain, with its present young people properly educated and trained in the crafts and industries which the country is capable of supporting and extending. There is also need for the captains of industry to be more than business men; they must have a sure knowledge and experience of the technique of their industry based upon a sound technical education, and possess a wide human outlook and sympathy with their workers.

There is not equality of opportunity for the boy who wishes for an industrial career and proceeds to

No. 2852 , VOL. I 13$]$ 